\title{
ABUNDANCE AND ETHNOMEDICINAL USE OF TREE AND SHRUB SPECIES IN AZAZA AND MOKLA FORESTS IN THE BLUE NILE STATE, SUDAN
}

\author{
Ikram Madani $^{1 *}$, Dafa Allah Ali Ibrahim², Hamad Mohamed Hamdeen ${ }^{3}$ \\ ${ }^{1,2}$ Department of Botany, Faculty of Science, University of Khartoum, Sudan \\ ${ }^{3}$ Department of Archaeology, El Neelian University, Khartoum, Sudan
}

"Corresponding Author: Ikram Madani

Article DOI: https://doi.org/10.36713/epra7634 DOI No: 10.36713/epra7634

\begin{abstract}
Documentation of medicinal plants utilization as an important non-timber forest resources are essential for their restoration and preservation. The present research aims to study the abundance of trees and shrubs in Azaza and Mokla forest in the Blue Nile state and to document their traditional use by two communities of Falata tribe living in the same locality. Field surveys were conducted during the period July-November in 2016 and 2017 following timed-meander survey method. Abundant, frequent, occasional, infrequent, and rare species were estimated. Ethnomedicinal data were collected using semistructured questionnaires. Documentation was taken from a total of 43 informants. 23 informants from Flata Willa in Amara Seraifa village which is located about $30 \mathrm{Km}$ north of Roseires dam and 20 informants from Falata Odda who are displaced by the dam lake and now resettled in City3 which located south east of the dam lake. A total of 28 medicinal trees and shrubs were identified in the studied forests. The most utilized plant families were leguminosae followed by Malvaceae Apocynaceae, and Zygophyllaceae. The highest proportion of the medicinal plants are trees (68\%) and the common treated diseases are stomach pain, respiratory inflammation, haemorrhoid, heart pain, uteritis, anemia, kidney disease, and dysentery. The study recommended further pharmacological and phytochemical research to study the efficiency of these plants to cure the diseases as well as sustainable management approach and proper conservation strategy to be integrated into forest management planning and activities for protection of the studied forests.
\end{abstract}

KEYWORDS: Ethnomedicine; plants; forest; Blue Nile; Sudan

\section{INTRODUCTION}

Non-timber forest products play a significant and critical role in improving livelihoods to a large part of the world's population (Belcher, 2005; Heubes et al, 2012). These products have long formed a vital component of people's everyday needs such as energy, food, raw materials for building, and medicines (Campbell and Luckert, 2002). Medicinal plants are one of the important non-timber forest resources that entering world market every year (Iqbal, 1993).70-80\% of people worldwide rely mainly on traditional herbal medicine to meet their primary healthcare needs (Shengji, 2001) The exploration, utilization and conservation of these resources are essential for restoration and preservation of traditional and indigenous knowledge (Reddy, 2012). In Sudan, although extensive areas of woodland and forest have been converted to agricultural use since the early 1900s (Harrison and Jackson, 1958), Still most of the natural forest products considered as an important source of income especially in the Blue Nile state (El Mamoun and El Zein, 2012). Modern health care systems in this area are not sufficient. The main source of their remedies is mainly plants. The present study aims to document the abundance of trees and shrubs in Azaza and Mokla forest in Al Roseires locality of the Blue Nile state and to explore and document their traditional use by two communities of Falata tribe living in the same locality 


\section{MATERIALS AND METHODS}

This study was conducted in the Blue Nile state which is a regional state located in the southern part of Sudan. The total area of the State is approximately $45,844 \mathrm{~km}^{2}$ and an estimated population of 1,193,293. This study is confined to Azaza (N:11 49894 E:34 30 331) and Mokla (N:11 34659 E:34 50 827) forests in Al Roseires area. which is the largest locality of the Blue Nile state. (Figure1). According to the vegetation cover map of Sudan, Blue Nile state is in the zone of low rainfall woodland savanna (Harison and Jackson, 1958). Its economic activity is based on agriculture and livestock. Collections of trees and shrubs in studied forest were conducted during the period JulyNovember in 2016 and 2017 following timed-meander survey method adopted by Cropper (1993). Specimens were identified consulting relevant floras and publications of Andrews $(1950 ; 1952 ; 1956)$ and El Amin (1990). Names are updated according to Plant List (2021). Families were arranged according to the Linear Angiosperm Phylogeny Group (APG III) (Haston et al. 2009). Vernacular names were reported from local people and available literature (Andrews 1953, 1957). Species abundance in the studied forest was conducted according to the scale proposed by Palmer et al. (1995). Abundant, frequent ,occasional, infrequent, and rare species were estimated. Ethnobotanical surveys were carried out during July 2017 using semi-structured questionnaires. Documentation was taken from a total of 43 informants belonging to two different branches of the Flata tribe. 23 informants from Flata Willa in Amara seraifa village which is located about $30 \mathrm{Km}$ north of Roseires dam and 20 informants from Falata Odda who are displaced by the dam lake and now resettled in City3 which located south east of the dam lake. Conversations were held at informants' homes with the assistance of wellknown local people and in focus group discussions in different sites in the studied areas. Ages of the informants ranged from 39 to 83 years with a mean of 60 years. Informants were asked about the plants and the harvested parts they use to cure the prevalent diseases, methods of preparing the herbal remedy, and administrative details.

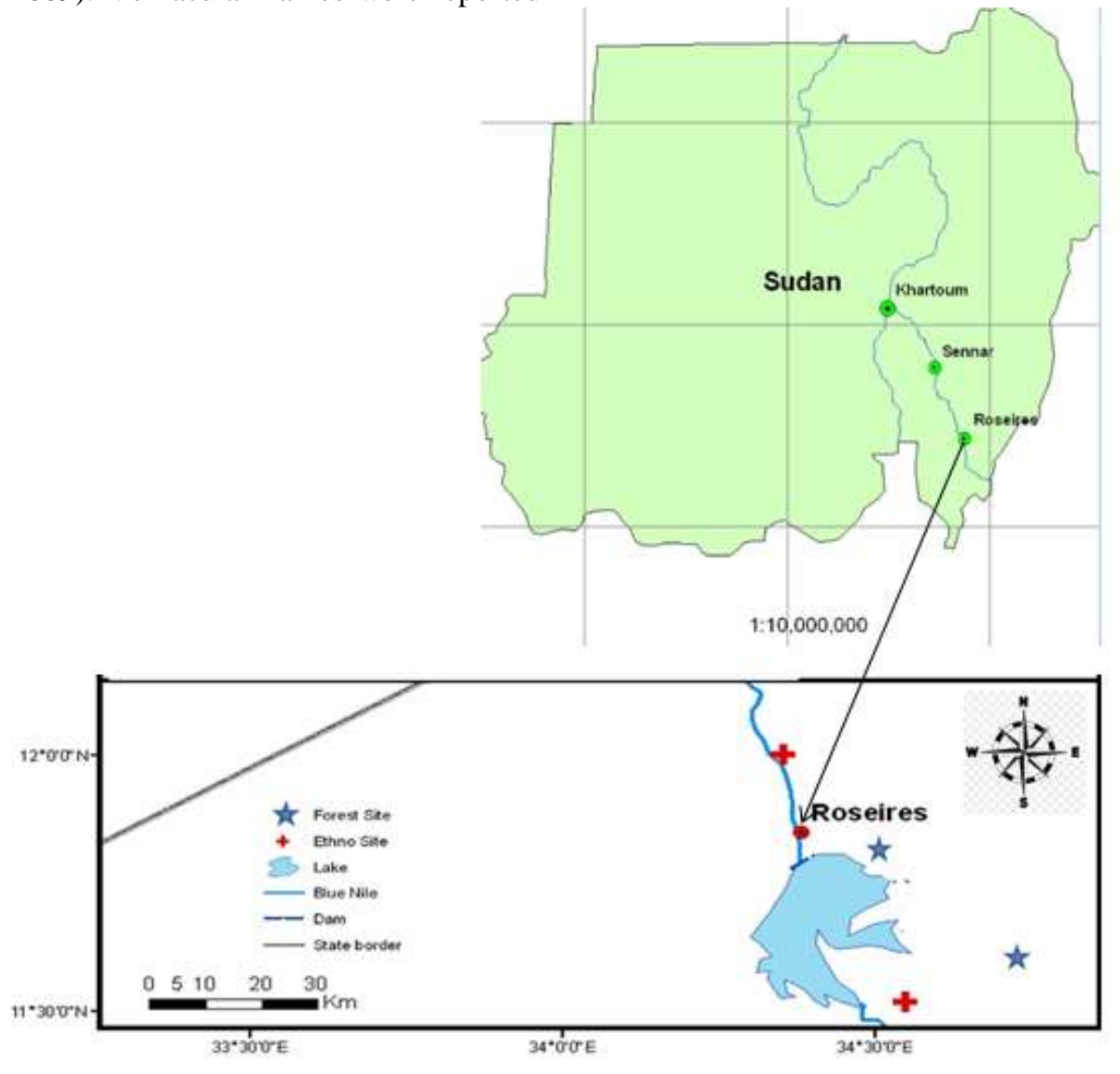

Figure1. Location of the study area 


\section{RESULTS AND DISCUSSION}

In this study, a total of 28 naturally growing tree and shrub species of medicinal values were identified and documented in Azaza and Mokla forests (Figure 2) shows the proportions of trees and shrubs in the studied forests. Species abundance in the two forests is presented in table 1. Acacia senegal, Sterculia Africana, Terminalia laxiflora, and Combretum glutinosum are the dominant species in Azaza forest while Anogeissus leiocarpus, Combretum glutinosum,
Dalbergia melanoxylon, Dichrostachys cinerea, Sterculia Africana, Ziziphus abyssinica, and Ziziphus spina-christi are the most dominant species in Mokla forest.

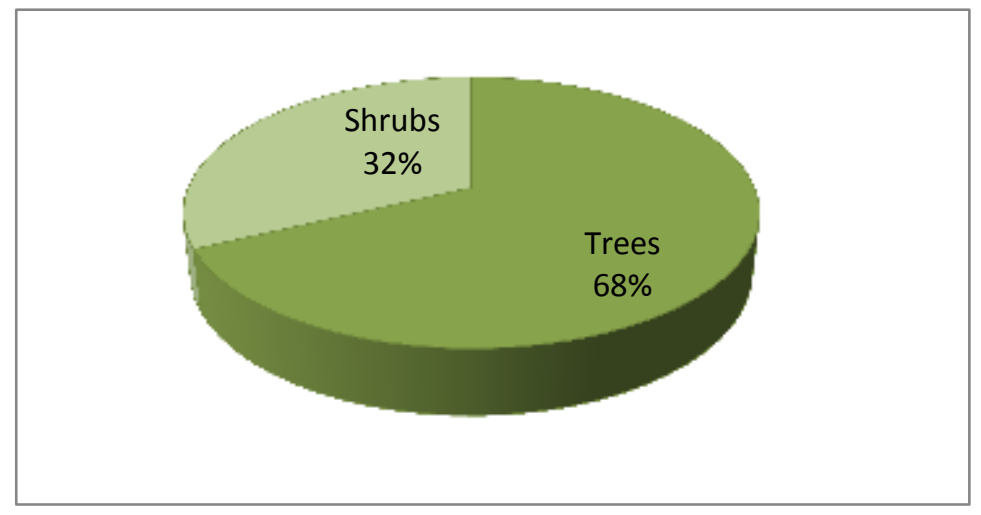

Figure2. Proportions of Ethnomedicinal trees and shrubs in the studied forests

Leaves, stem, bark, flowers, roots, seeds, and gum are the plants parts used by Falata Wila and Falata Odda tribal communities for remedies of diseases like stomach pain, respiratory inflammation, haemorrhoid, heart pain, uteritis, anemia, and kidney disease (Table 2). Leaves, bark, and roots are the most used parts of the plants. Figure 2 shows the proportions of the plant parts used. The most utilized plant families were leguminosae (12 species) followed by Malvaceae, Apocynaceae, Zygophyllaceae (three species), and Combretaceae (two species) and one species from the families Burseraceae, Arecaceae, Papaveraceae, Meliaceae, and Lamiaceae. Figure 3. Interviews revealed that methods of preparation and application of the remedies were transmitted, most of the young generations are now using these traditional medicine. 
ISSN (Online): 2455-3662

EPRA International Journal of Multidisciplinary Research (IJMR) - Peer Reviewed Journal

Volume: 7 | Issue: 7 | July 2021|| Journal DOI: 10.36713/epra2013 || SJIF Impact Factor 2021: 8.047 || ISI Value: 1.188

\begin{tabular}{|c|c|c|c|}
\hline \multirow[b]{2}{*}{ Species } & \multirow[b]{2}{*}{ Local name } & \multicolumn{2}{|c|}{ Abundance } \\
\hline & & $\begin{array}{c}\text { Azaza forest } \\
(\mathrm{N}: 1149894 \mathrm{E}: 3430 \\
331)\end{array}$ & $\begin{array}{c}\text { Mokla forest } \\
(\mathrm{N}: 1134659 \mathrm{E}: 3450 \text { 827) }\end{array}$ \\
\hline Acacia foetida (Jacq.) Kunth & Lawot & +++ & + \\
\hline Acacia polycantha Willd. & Kakmoot & ++++ & +++ \\
\hline Acacia senegal (L.) Willd. & Hashab & +++++ & +++ \\
\hline Adansonia digitata $L$. & Tbaldi & +++++ & ++++ \\
\hline Anogeissus leiocarpus (DC.) Guill. \& Perr. & Silk & +++ & +++++ \\
\hline Argemone mexicana L. & Khashkhash & + & + \\
\hline Azadirachta indica A. Juss & Neem & ++ & ++ \\
\hline Balanites aegyptiaca (L.) Delile & Laloub & +++ & ++++ \\
\hline Boscia senegalensis Lam. & Mokheet & +++ & ++ \\
\hline Boswellia papyrifera (Caill. ex Delile) Hochst & Trag trag & ++ & ++ \\
\hline Calotropis procera (Aiton) Dryand. & Oshar & +++ & ++ \\
\hline Capparis decidua (Forssk.) Edgew & Tundob & + & + \\
\hline Cassia arereh Del & Gaga & + & ++ \\
\hline Combretum glutinosum Perr. ex DC. & Habeel & ++++ & +++++ \\
\hline Dalbergia melanoxylon Guill & Babanose & ++++ & +++++ \\
\hline Dichrostachys cinerea (L.) White \& Arn. & Kadad & +++ & +++++ \\
\hline Grewia mollis Juss. & Godam & +++ & ++++ \\
\hline Hyphaene thebaica (L.) Mart. & Dom & + & + \\
\hline Ocimum basilicum L. & Rehan & ++ & ++ \\
\hline Pterocarpus lucens Guill. \& Perr. & Taraya & ++ & ++++ \\
\hline Senna alexandrina Mill. & Sana sana & +++ & +++ \\
\hline Senna tora (L.) Roxb. & pargahi & +++ & +++ \\
\hline Sterculia africana Fiori. & Tartr & +++++ & +++++ \\
\hline Stereospermum kunthianum Cham. & Khash khash & +++ & +++ \\
\hline Tamarindus indica $L$. & Aradeeb & +++ & +++ \\
\hline Terminalia laxiflora Engl. & Sobag & +++++ & ++++ \\
\hline Ziziphus abyssinica Hochst. ex A.Rich. & Seder feel & ++ & +++++ \\
\hline Ziziphus spina-christi (L.) Desf. & Seder & ++ & +++++ \\
\hline
\end{tabular}

Table1. Trees and shrubs abundance in the studied forests

Key: (Abundance is according to scale proposed by Palmer et al. (1995): Abundant+++++; frequent ++++;

Occasional +++; Infrequent ++; Rare +) 
ISSN (Online): 2455-3662

EPRA International Journal of Multidisciplinary Research (IJMR) - Peer Reviewed Journal

Volume: 7 | Issue: 7 | July 2021|| Journal DOI: 10.36713/epra2013 || SJIF Impact Factor 2021: 8.047 || ISI Value: 1.188

\begin{tabular}{|c|c|c|c|c|c|}
\hline Species & Local name & Habit & Part used & preparation & Medicinal use \\
\hline Acacia foetida (Jacq.) Kunth & Lawot & Tree & Leaf & paste & Tonsillitis \\
\hline Acacia polycantha Willd. & Kakmoot & Tree & Bark \& root & Decoction & Stomach pain \\
\hline Acacia senegal (L.) Willd. & Hashab & Tree & Gum & $\begin{array}{c}\text { Raw or } \\
\text { maceration }\end{array}$ & Kidney pain \\
\hline Adansonia digitata $L$. & Tbaldi & Tree & Fruit & Maceration & Dysentery \\
\hline Anogeissus leiocarpus (DC.) Guill. \& Perr. & Silk & Tree & Bark & decoction & Inflammation/ back pain \\
\hline Argemone mexicana $L$. & Khashkhash & Shrub & Bark & Maceration & Ant venom \\
\hline Azadirachta indica A. Juss & Neem & Tree & Leaf & Decoction & Malaria \\
\hline Balanites aegyptiaca (L.) Delile & Laloub & Tree & Fruit & Maceration & $\begin{array}{l}\text { Stomach pain/ } \\
\text { haemorrhoid }\end{array}$ \\
\hline Boscia senegalensis Lam. & Mokheet & Tree & Flower+ bark & Decoction & Respiratory inflammation \\
\hline $\begin{array}{l}\text { Boswellia papyrifera (Caill. ex Delile) } \\
\text { Hochst }\end{array}$ & Trag trag & Shrub & Leaf & Paste & Haemorrhoid \\
\hline Calotropis procera (Aiton) Dryand. & Oshar & Shrub & Root & Decoction & Diarrhea \\
\hline Capparis decidua (Forssk.) Edgew & Tundob & Tree & Leaf \&stem & Maceration & Vomiting \\
\hline Cassia arereh Del & Gaga & Shrub & Root & Maceration & $\begin{array}{l}\text { Stomach pain/ dysentery/ } \\
\text { scorpion and ant venom }\end{array}$ \\
\hline \multirow{2}{*}{ Combretum glutinosum Perr. ex DC. } & \multirow{2}{*}{ Habeel } & \multirow{2}{*}{ Tree } & \multirow{2}{*}{ Bark } & Decoction & Inflammation \\
\hline & & & & Paste & Hemorrhoid \\
\hline Dalbergia melanoxylon Guill . & Babanose & Tree & Root & Raw & Sexual catalytic \\
\hline Dichrostachys cinerea (L.) White \& Arn. & Kadad & Tree & Leaf & Raw & Heart pain \\
\hline Grewia mollis Juss. & Godam & Tree & Fruit & Infusion & Anemia \\
\hline Hyphaene thebaica (L.) Mart. & Dom & Tree & Fruit & Maceration & Hypertension/ typhoid \\
\hline Ocimum basilicum L. & Rehan & Shrub & Leaf & Decoction & Headache \\
\hline Pterocarpus lucens Guill. \& Perr. & Taraya & Shrub & Bark & Maceration & Kidney disease \\
\hline Senna alexandrina Mill. & Sana sana & Shrub & Leaf \& seed & Decoction & Stomach pain \\
\hline Senna tora (L.) Roxb. & pargahi & Shrub & Bark & Decoction & Uteritis \\
\hline \multirow{2}{*}{ Sterculia africana Fiori. } & \multirow{2}{*}{ Tartr } & \multirow{2}{*}{ Tree } & \multirow[t]{2}{*}{ Bark } & Burnt & Uteritis \\
\hline & & & & Maceration & Coldness \\
\hline Stereospermum kunthianum Cham . & Khash khash & Shrub & Bark & Decoction & Uterine bleeding \\
\hline Tamarindus indica $L$. & Aradeeb & Tree & Fruit & Maceration & Stomach pain/ Diarrhea \\
\hline Terminalia laxiflora Engl. & Sobag & Tree & Bark & Decoction & Respiratory inflammation \\
\hline Ziziphus abyssinica Hochst. ex A.Rich. & Seder feel & Tree & Leaf & Paste & Abscess \\
\hline Ziziphus spina-christi (L.) Desf. & Seder & Tree & Fruit \& leaf & Maceration & Stomach pain \\
\hline
\end{tabular}

Table 2. List of Medicinal plants used by two communities of Falata tribe in the studied area 


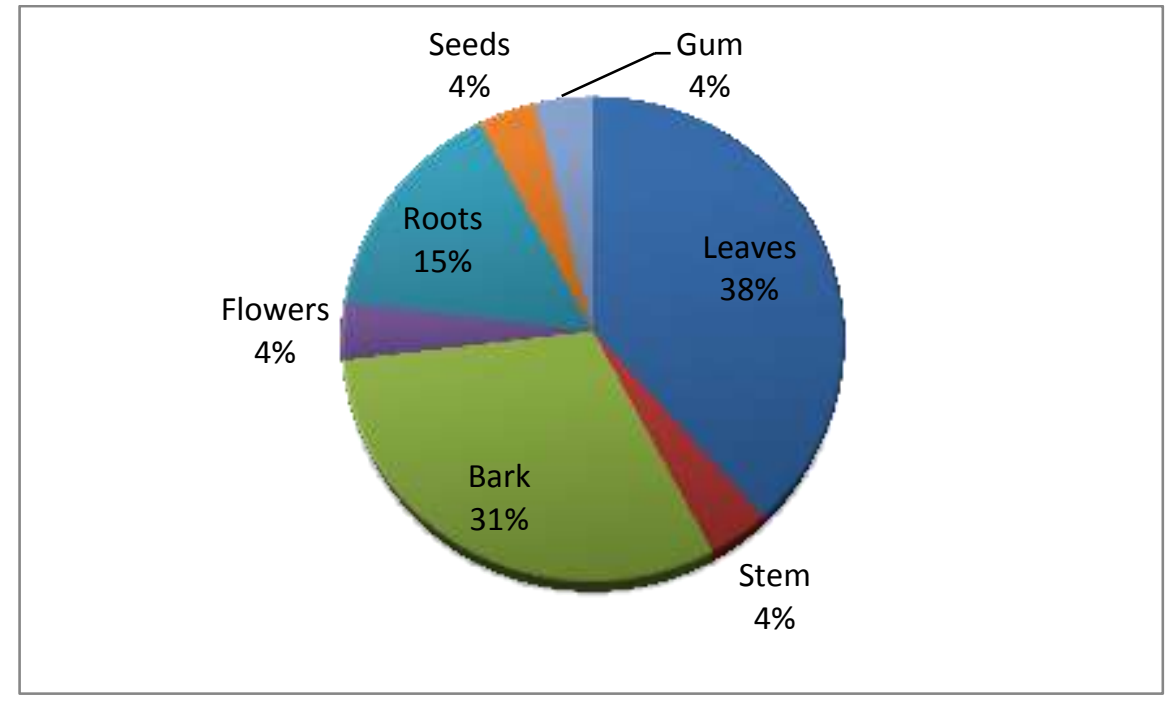

Figure 2. Ethno medicinal plants: Different plant parts used in the study area

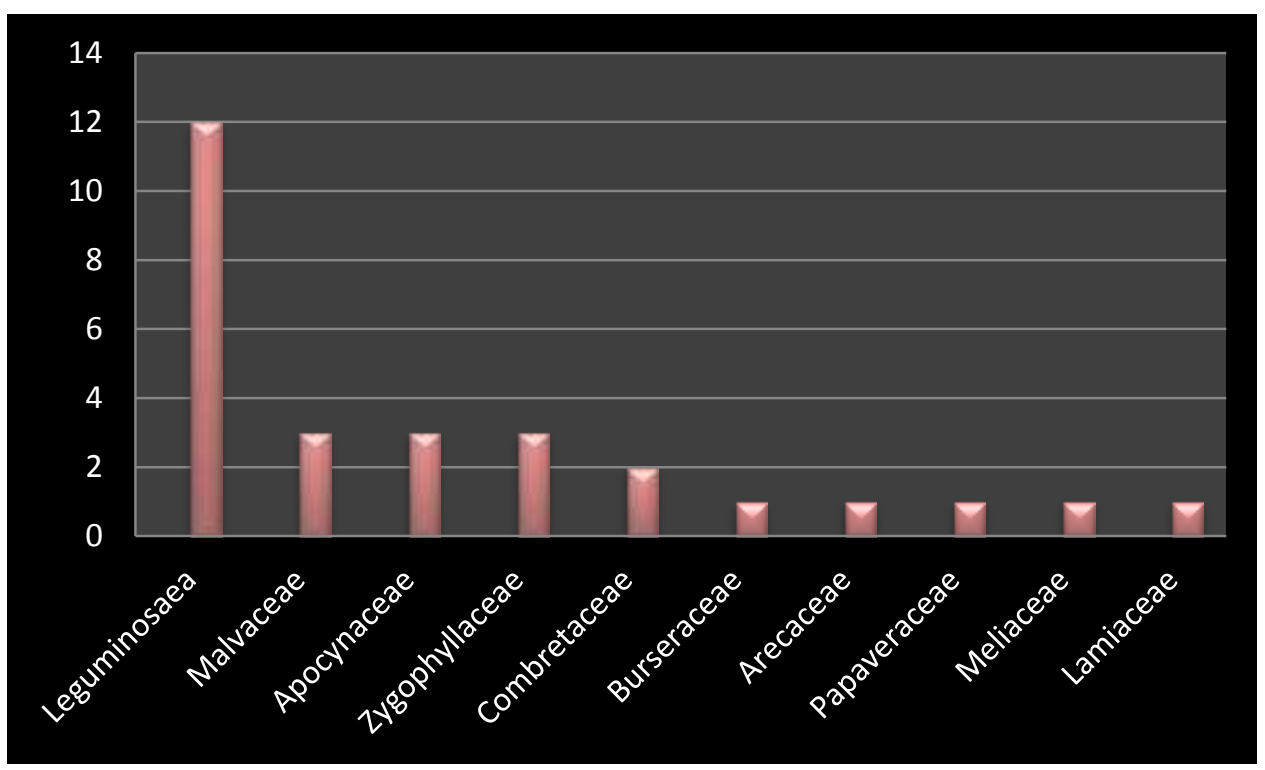

Figure 3. Ethno medicinal plants: the proportions of the plants used by families

It is observed that the use of leaves of Ziziphus spina-christi as an effective remedies to treat stomach pain was also documented for the Barti tribe in Sennar state (Ahmed et al, 2020). The use of leaves of Hyphaene thebaica by Kababish tribe in the northern Sudan for the treatment of hypertension were reported by Ahmed et al (2014) People from the different tribes Barti, Kababish and Falata agree to use acacia seyal stem for the treatment of rheumatic pain.

\section{ACKNOWLEDGEMENT}

Authors gratefully acknowledge the funding of this work by the Ministry of higher Education and Scientific Research, Sudan and would also like to express appreciation for the support of the Sudanese Electricity Distribution Company Ltd. and the valuable help and cooperation of the informants and locals in Amara Seriafa, Azaza, and Mokla areas . 


\section{CONCLUSION}

This research documented the species diversity and abundance of trees and shrubs of Azaza and Mokla forest in the Blue Nile State and contributes on documentation of medicinally important species. The study revealed that Falata Willa and Falata Odda tribes, which lives in the vicinity of the studied forest used 28 plants to treat various ailments. The most utilized plant families were leguminosae followed by Malvaceae Apocynaceae, and Zygophyllaceae. The highest proportion of the medicinal plants are the trees $(68 \%)$ and the common treated diseases are stomach pain, respiratory inflammation, haemorrhoid, heart pain, uteritis, anemia, kidney disease, and dysentery. The study recommended further pharmacological and phytochemical research to study the efficiency of these plants to cure the diseases as well as sustainable management approach and proper conservation strategy to be integrated into forest management planning and activities for protection of this non-timber forest products .

\section{REFERENCES}

1. Ahmed, I. M. , Tahir, Y. .F \& Nour, S. M. (2014) Ethnobotanical study of medicinal plants used by El Kababish tribe in Ga'ab El Lagia Oasis, West Dongla (Sudan). Nyame Akuma Bulletin 82: 91-99

2. Ahmed I. M., Tahir, Y. F., Nour, S.M. \& Suliman, M. A. (2020) Traditional use of medicinal plants among the Barti tribe community in Fangoga area, Sennar State, Sudan. Tropical Plant Research 7(2): 517-521

3. Andrews, F. W. (1950. 1952, 1956): The Flowering Plants of the Anglo-Egyptian Sudan, Vols. 1-3 T. Arbroath: Buncle and Co. Ltd.

4. Andrews, F.W. (1953, 1957): Vernacular Names of Plants as described in "Flowering Plants of the (Anglo-Egyptian) Sudan. Vols. 2,3". Mc Corquodale \& Co. (Sudan), Ltd

5. Belcher, B. M (2005) "Forest product markets, forests and poverty reduction," International Forestry Review, vol. 7, no. 2, pp. 82-89, Heubes, K.

6. Campbell, B. M. and Luckert, M. K. (2002) Uncovering the Hidden Harvest. Valuation Methods for Woodland and Forest Resources, Earthscan, London

7. Cropper, S. (1993): Management of endangered plants. Melbourne: CSIRO Publications.

8. El Mamoun, H.O. and El Zein, A., (2012) Species Dynamics and Potential Disturbances in El Nour Natural Forest Reserve, Sudan. Journal of forest products and industries, 1(2), 10-20 ISSN: 2166

9. El Amin, H. M. (1990): Trees and Shrubs of the Sudan. Exeter: Ithaca Press.

10. Harrison, M. N. and J.K. Jackson (1958): "Ecological classification of the vegetation of the
Sudan”, Forest Bulletin. No 2. (New series) Forest Dept., Khartoum

11. Haston, E., J.E. Richardson, P.F. Stevens, M.W. Chase and D.J. Harris (2009): "The Linear Angiosperm Phylogeny Group (LAPG) III: a linear sequence of the families in APG III", Botanical Journal of the Linnaean Society 161: 128-131. https://doi.org/10.1111/j.1095-8339.2009.01000.x

12. Heubach, M. Schmidt et al. (2012) "Impact of future climate and land use change on non-timber forest product provision in Benin, West Africa: linking niche-based modeling with ecosystem service values," Economic Botany, vol. 66, no. 4, pp. 383-397

13. Iqbal, M. (1993). International trade in non-wood forest products: an overview. FO: Misc/93/11 Working Paper. Food and Agricultural Organization of the United Nations, Rome

14. The Plant List (2013): The plant list version 1.1. Accessed at http://www.theplantlist.org March 2020

15. Palmer, M.W., G.L. Wade, P. Neal (1995): "Standards for the writing of floras", BioScience 45, 339-345 https://doi.org/10.2307/1312495

16. Reddy BM. (2012) Wild edible plants of Chandrapur district, Maharashtra, India. Indian J Nat Prod Resour.;3:110-7.

17. Shengji, P. (2001) Ethnobotanical approaches of traditional medicine studies: Some experiences from Asia. Pharm Bot, 39(1): 74-79 